University of Nebraska - Lincoln

DigitalCommons@University of Nebraska - Lincoln

\title{
A Focus of Human Infection by Haplorchis taichui (Trematoda: Heterophyidae) in the Southern Philippines
}

Vicente Y. Belizario Jr.

University of the Philippines Manila

Winifreda U. de Leon

University of the Philippines Manila

Mary Joan J. Bersabe

Center for Health Development for Southern Mindanao

Purnomo

U.S. Naval Medical Research Unit \# 2

J. Kevin Baird

U.S. Naval Medical Research Unit \# 2, jkevinbaird@yahoo.com

See next page for additional authors

Follow this and additional works at: https://digitalcommons.unl.edu/usnavyresearch

Belizario, Vicente Y. Jr.; de Leon, Winifreda U.; Bersabe, Mary Joan J.; Purnomo; Baird, J. Kevin; and Bangs, Michael J., "A Focus of Human Infection by Haplorchis taichui (Trematoda: Heterophyidae) in the Southern Philippines" (2004). U.S. Navy Research. 73.

https://digitalcommons.unl.edu/usnavyresearch/73

This Article is brought to you for free and open access by the U.S. Department of Defense at DigitalCommons@University of Nebraska - Lincoln. It has been accepted for inclusion in U.S. Navy Research by an authorized administrator of DigitalCommons@University of Nebraska - Lincoln. 
Authors

Vicente Y. Belizario Jr., Winifreda U. de Leon, Mary Joan J. Bersabe, Purnomo, J. Kevin Baird, and Michael J. Bangs

This article is available at DigitalCommons@University of Nebraska - Lincoln: https://digitalcommons.unl.edu/ usnavyresearch/73 


\title{
A Focus of Human Infection by Haplorchis taichui (Trematoda: Heterophyidae) in the Southern Philippines
}

\author{
Vicente Y. Belizario, Jr., Winifreda U. de Leon, Mary Joan J. Bersabe ${ }^{\star}$, Purnomo†, J. Kevin Baird †, and Michael J. Bangs $\nmid \neq$, College of \\ Public Health, University of the Philippines, Pedro Gil, Ermita, Manila, Philippines; ${ }^{*}$ Center for Health Development for Southern Mindanao, \\ Department of Health, Davao City, Philippines; †U.S. Naval Medical Research Unit No. 2 (NAMRU-2), Kompleks P2M/PLP, JI. Percetakan \\ Negara No. 29, Jakarta 10560, Indonesia; łTo whom correspondence should be addressed. e-mail: michael.bangs@ndvecc.navy.mil
}

ABSTRACT: We report an exceptionally high rate of infection by Haplorchis taichui (Nishigori, 1924) in human populations on Mindanao Island, southern Philippines. This intestinal fluke is seldom encountered, and this is the first report of high prevalence of infection (36\%) in humans by $H$. taichui in the Philippines. The likely source of haplorchine infection has been linked to consumption of raw or undercooked freshwater fish containing infective metacercariae. The most common clinical symptoms appeared as upper abdominal discomfort or pain and borborygmi. Praziquantel $(75 \mathrm{mg} / \mathrm{kg}$ divided in 3 doses in 1 day) was a well-tolerated and effective treatment for infection by $H$. taichui.

Food-borne trematodiases are an important cause of disease in humans that create an adverse economic impact in endemic tropical areas (Rim et al., 1994; WHO, 1995). Until recently, the prevalence of heterophyidiasis in humans had been reported as very low in the Philippines. For example, less than $1 \%$ of more than 30,000 stool specimens examined in nationwide surveys during 1970-1980 were found to contain heterophyid ova (Cross and Basaca-Sevilla, 1984), with site-specific infection rates not exceeding 3\%. Intestinal parasite surveys were conducted in 1998 and 1999 in 2 communities in Monkayo, Compostela Valley Province, southern Mindanao in connection with an outbreak of intestinal capillariasis (Belizario et al., 2000). Survey results indicated heterophyid infection rates of $17 \%$ and $16 \%$, respectively, in the general population (Belizario et al., 2000, 2001). Infections were reported as heterophyid (Heterophyidae) flukes on the basis of egg size and morphology, without definitive species identification. This report examined adult worms recovered after treatment of patients given praziquantel and provides conclusive identification of Haplorchis taichui (Trematoda: Heterophyidae) as the parasitic agent. Additional epidemiological background on the investigations conducted in 2000 from infection foci, including symptomatology and treatment of $H$. taichui infections, is provided. All clinical aspects of the investigation were conducted in full accordance with Good Clinical Practice Guidelines and provisions of the World Medical Association Declaration of Helsinki (amended, 1996).

The barangay (village) of San Isidro is in the municipality of Mon- 
TABLE I. Age and sex distribution of study participants and those infected with Haplorchis taichui infection in Barangay San Isidro, Monkayo, Compostela Valley, May 2000.

\begin{tabular}{|c|c|c|c|c|c|c|}
\hline \multirow[b]{2}{*}{$\begin{array}{l}\text { Age } \\
\text { group }\end{array}$} & \multicolumn{2}{|c|}{ Male } & \multicolumn{2}{|c|}{ Female } & \multicolumn{2}{|c|}{ Total } \\
\hline & $\begin{array}{c}\text { No. } \\
\text { examined }\end{array}$ & $\begin{array}{l}\text { No. }(\%) \\
\text { infected }\end{array}$ & $\begin{array}{c}\text { No. } \\
\text { examined }\end{array}$ & $\begin{array}{l}\text { No. }(\%) \\
\text { infected }\end{array}$ & $\begin{array}{c}\text { No. } \\
\text { examined }\end{array}$ & $\begin{array}{l}\text { No. }(\%) \\
\text { infected }\end{array}$ \\
\hline$<5$ & 13 & $3(23$ & 23 & $3(1$ & 36 & $6(1$ \\
\hline $5-1$ & 36 & $11(3$ & 26 & 6( & 62 & 17 (27.4) \\
\hline $15-30$ & 25 & 16( & 22 & 10( & 47 & $26(55.3)$ \\
\hline $31-45$ & 34 & 17( & 29 & $11(3$ & 63 & $28(44.4)$ \\
\hline $46-60$ & 8 & $2(25.0)$ & 9 & $2(22.2)$ & 17 & $4(23.5)$ \\
\hline$>60$ & 6 & $2(33.3)$ & 11 & $4(36.4)$ & 17 & $6(35.3)$ \\
\hline Total & 122 & $51(41.8)$ & 120 & $36(30.0)$ & 242 & $87(36.0)$ \\
\hline
\end{tabular}

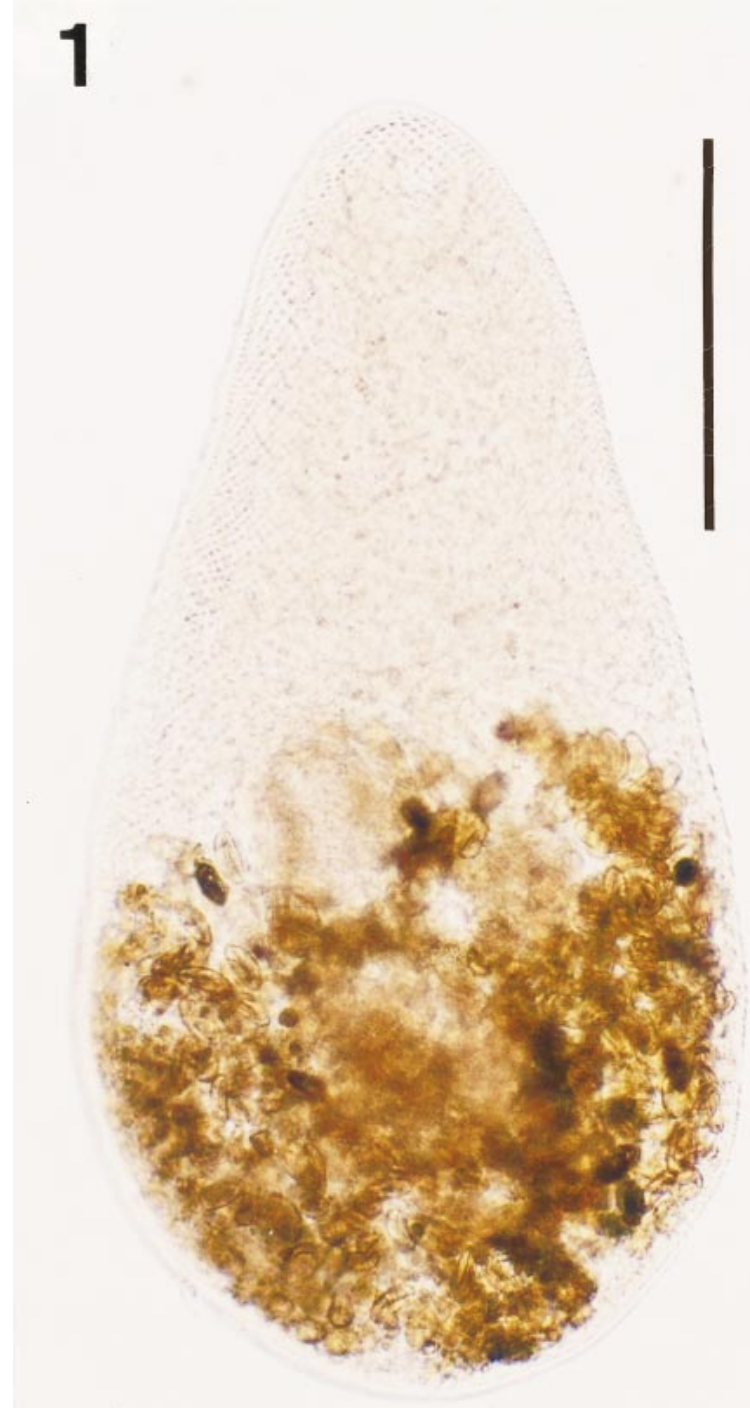

kayo, Compostela Valley Province, southern Mindanao (Region XI), Philippines, and located inland $\sim 100 \mathrm{~km}$ north of coastal Davao City. Farming is the most common occupation, with corn as the major cultivated crop, followed by rice, coconut, and banana. Based on Rural Health Unit (RHU) records, nearly 35\% of interviewed households (n $=270$ ) did not have dedicated toilet-latrine facilities. The people of San Isidro obtain water from 2 primary sources, i.e., rainwater and the Saug River. Rainwater is preferred for cooking and washing purposes. The river regularly provides freshwater fish, crabs, shrimps, and snails that supplement the diet with additional protein. A detailed description of the study site has been provided elsewhere (Belizario et al., 2000).

A cross-sectional, active case detection survey was conducted in May 2000 in San Isidro. Health interviews and stool samples were obtained from residents with a history of recent bowel disturbance (abdominal discomfort or pain, or diarrhea, or both). The principal complaints, signs, and symptoms were noted, and a fresh stool specimen was obtained from each patient. Stool was examined as wet mounts using either the Kato thick smear (Kato-Katz) technique or the formalin-ether sedimentation technique (FEST) (Ash and Orihel, 1987; WHO, 1998). Processed stool samples were initially examined under the microscope

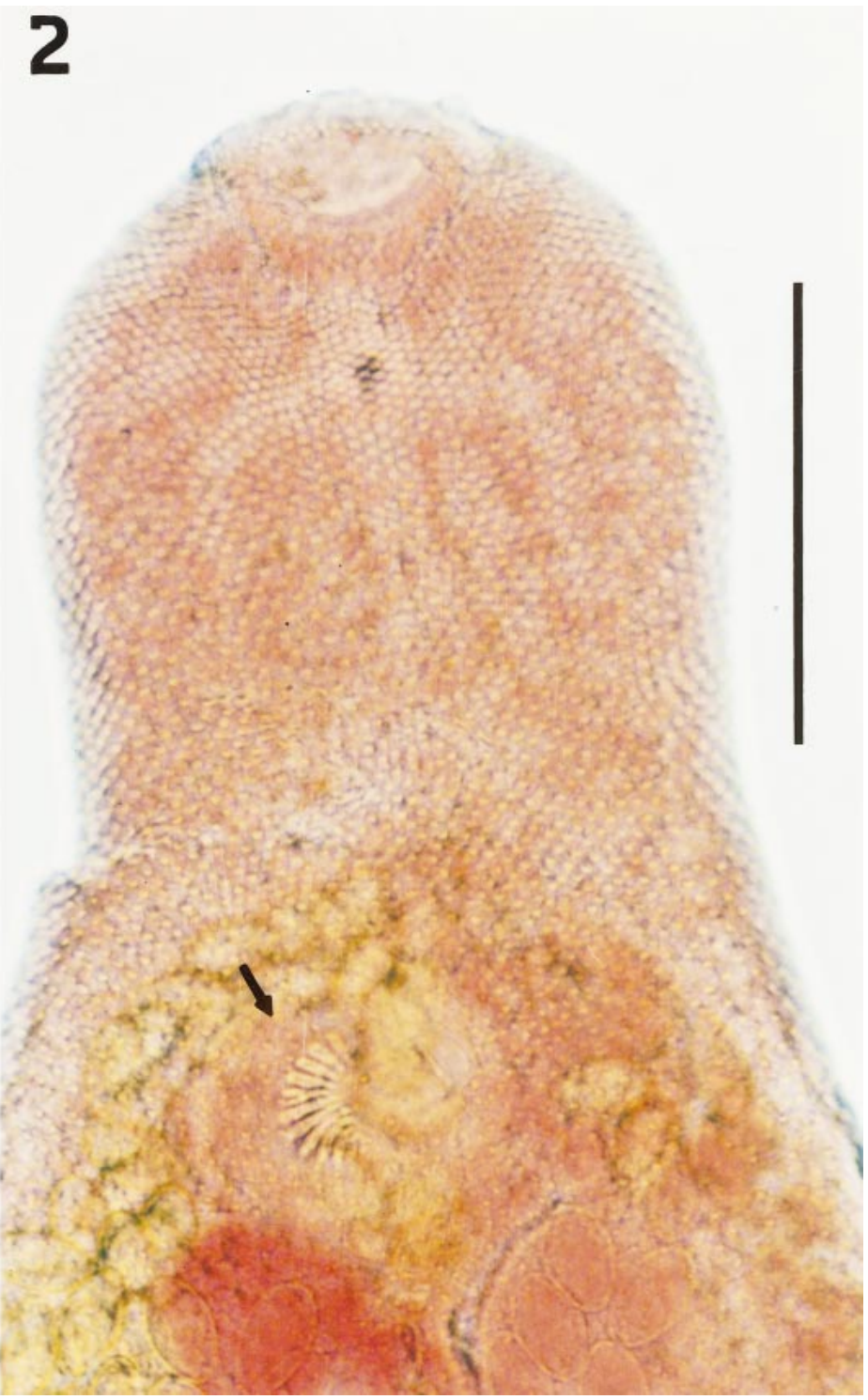

FiguRES 1-2. Haplorchis taichui (Nishigori) 1. Pyriform adult, glycerin whole mount, unstained, showing transverse rows of scale-like spines on tegument. Bar: $200 \mu \mathrm{m}$. 2. Carmine-stained anterior portion of adult worm showing subterminal oral sucker and ventrogenital complex (small arrow) containing ventral sucker armed with prominent spines. Bar: $100 \mu \mathrm{m}$. 


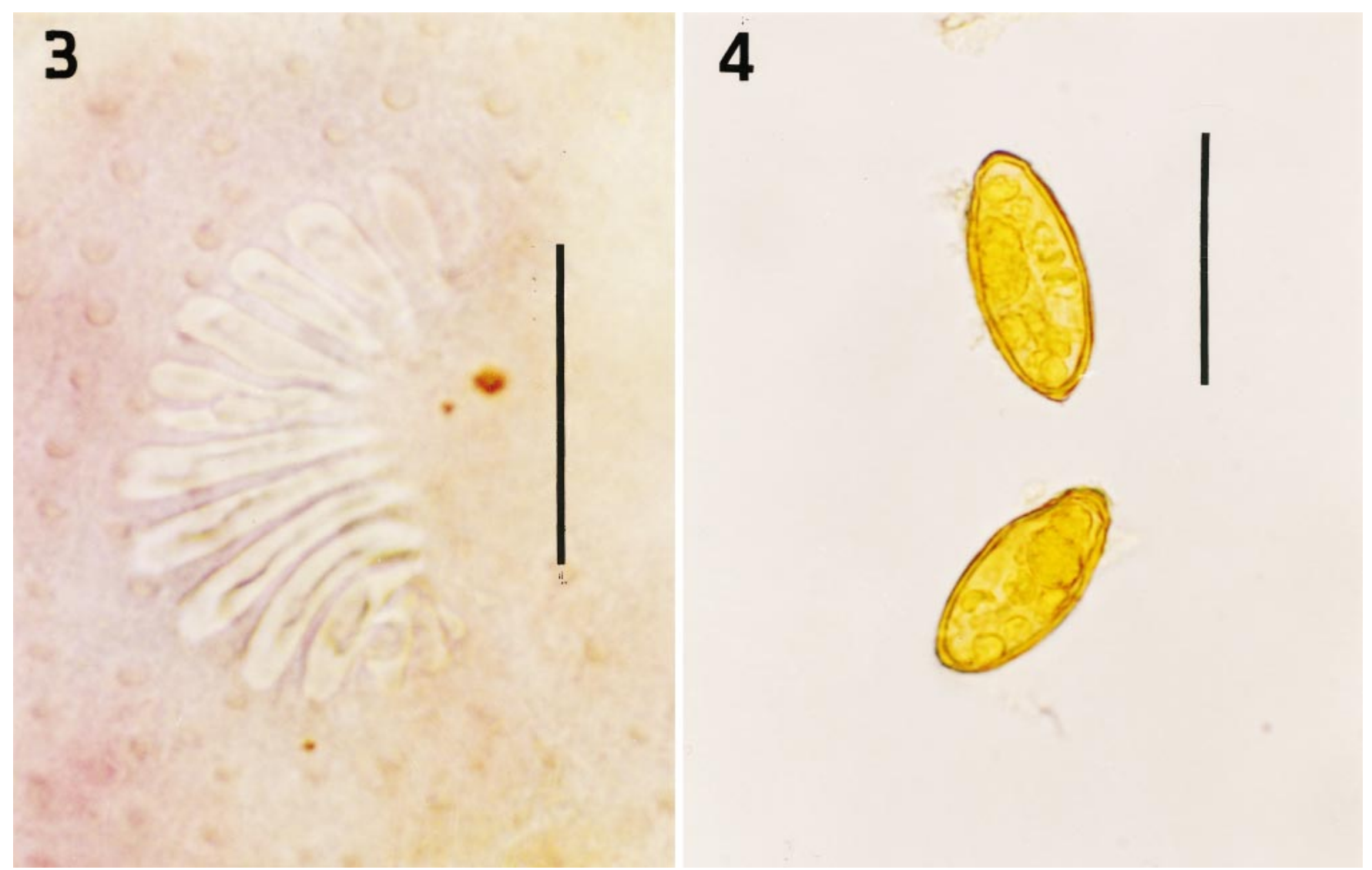

FIGURES 3-4. Haplorchis taichui 3. Ventral sucker with crescentic group of 14 hollow spines (sclerites). Bar: $25 \mu \mathrm{m}$. 4. Operculated eggs (30-35 $\mu \mathrm{m}$ long, 15-18 $\mu \mathrm{m}$ wide) from stool showing prominent "shoulders" at apex and thickened posterior prominence. Bar: $30 \mu \mathrm{m}$.

by trained microscopists assigned to the local government health facilities, with on-site cross-checking conducted by staff from the Diagnostic Parasitology Laboratory, College of Public Health, University of the Philippines Manila (UP-CPH). A subsequent independent quality control of sample results was conducted by UP-CPH. Using the Kato-Katz technique, heterophyid eggs in stool were counted along with other helminths (Ascaris lumbricoides, Trichuris trichiura, Capillaria philippinensis, and hookworm eggs) (Belizario et al., 2001). Heterophyid eggs were counted on a standardized template grid and multiplied by a factor of 24 to approximate the number of eggs present per gram (epg) of feces. A classification of infection intensity ('burden') was used to represent light (1-100 epg), moderate (101-1,000 epg), and heavy ( $>1,000$ epg) infections (Belizario et al., 2001).

Sixty-seven patients infected with $H$. taichui were given commercially available praziquantel (Distocide ${ }^{\circledR}$, Shin Poong Pharm. Co., Ltd., Seoul, Republic of Korea), $75 \mathrm{mg} / \mathrm{kg}$, divided in 3 doses in 1 day. Stool specimens were collected from 35 patients between 7 and 14 days after treatment and examined using the Kato-Katz technique. The Monkayo RHU microscopist performed the initial examination in the field, and the $10 \%$ formalin-fixed specimens were later forwarded to the UP-CPH Diagnostic Parasitology Laboratory for crosschecking and confirmation. Patient response to drug treatment was categorized as one of the following: (1) clinical cure, i.e., absence of eggs on repeat stool examination; (2) clinical improvement, i.e., lower intensity of associated symptoms and infection (eggs) on repeat examination; (3) clinical failure, i.e., similar or higher intensity of infection on repeat stool examination; and (4) indeterminate, i.e., no repeat stool examination possible (patient loss to follow-up or noncompliance).

Use of the Kato-Katz method or FEST revealed that 87 patients had evidence of heterophyidiasis, i.e., an overall infection rate of $36.0 \%$ (Table I). From fresh stool, the Kato-Katz method revealed $31 \%$ of samples with heterophyid ova compared with $13.6 \%$ for FEST. Haplorchis taichui infection was seen in all age groups from 19 mo to 73 yr of age (mean 27.2). Infection prevalence was greatest $(55.3 \%)$ in the 15-30-yr-old age group, followed by the 31-45-yr-old cohort, together representing $62 \%$ of the sampled population found infected among the 6 age groups. Infection prevalence was generally higher in age groups $5 \mathrm{yr}$ and older, although $16.7 \%$ of children less than $5 \mathrm{yr}$ of age had $H$. taichui infection. Overall, male subjects had a higher, but not statistically significant (chi-square, $P<0.05$ ), infection prevalence compared with females $(30 \%)$. The majority of cases $(71 \%)$ had moderate to heavy infection burdens, particularly patients $>15 \mathrm{yr}$ of age. Most cases in age groups below $15 \mathrm{yr}$ had light infections. The infection burden (estimated egg density) ranged from 24 to $26,256 \mathrm{epg}$, with a mean (geometric) egg count of 256 epg.

In San Isidro, 83 patients were interviewed for clinical signs and symptoms associated with $H$. taichui infection. A review of their histories showed that $38(45.8 \%)$ patients complained of peptic ulcer-like symptoms, with upper abdominal discomfort or pain reported by 35 (42.2\%), followed by borborygmi in $20(24.1 \%)$ cases. Other complaints included nausea, chronic diarrhea, and weight loss. Fourteen (16.9\%) patients reported no complaints and were considered asymptomatic. Although this was not a case-control study, most symptoms associated with $H$. taichui infection quickly resolved after completing the 1-day praziquantel treatment.

Thirty-five $(52.2 \%)$ patients submitted specimens for follow-up stool examination after treatment. Using the Kato-Katz technique, 11 patients $(31.4 \%)$ were found to have at least 1 helminth species infection. Only 1 patient $(2.9 \%)$ had stool containing heterophyid eggs. The arithmetic and geometric means of Haplorchis egg reduction in stool were $99.3 \%$ and $98.4 \%$, respectively, with an overall cure of $97 \%$. Similarly, complete clinical cure was seen in 34 of $35(97 \%)$ patients, with significant clinical improvement seen in the 1 patient who did not completely recover. None of the treated follow-up patients exhibited clinical failure. Clinical outcome was indeterminate in $40(53.3 \%)$ of the treated patients because of loss to follow-up. In agreement with Radomyos et al. (1998), 
1-day praziquantel administration appears well tolerated and effective against $H$. taichui and could be considered for use in a mass treatmentcontrol campaign.

Fresh stool specimens were obtained after treatment with praziquantel and fixed in $10 \%$ formalin for later study. For the identification of the heterophyid specimens, formalin-preserved stool was prepared as a standard direct wet mount and stained with iodine for detection of ova. Egg morphology identified a heterophyid-like origin but could not provide definitive species diagnosis. Formalin-preserved adult flukes were washed in physiological saline solution, mounted whole, either unstained or stained with carmine red, and mounted in Canada balsam (Ash and Orihel, 1987). The condition of adult worms recovered from formalin-preserved stool varied from excellent to slight disfigurement of the integument. In most cases, preserved worms expelled after treatment with praziquantel could be adequately stained and identified. Photographic documentation was made using a Nikon UFX-DX microscope system (Figs. 1-4). All adult worms examined (Figs. 1-2) conformed to taxonomic descriptions for the genus Haplorchis Looss 1899 and specifically to H. taichui (Pearson and Ow-Yang, 1982). Of particular differential diagnostic importance is the ventrogenital complex with a distinctive ventral sucker containing a crescentric group of 12-16 hollow sclerites, some ending in a laterodorsal notch (Fig. 3). Operculated, thick-shelled eggs (30-35 $\mu \mathrm{m}$ long, 15-18 $\mu \mathrm{m}$ wide) examined from stool were within the described size range for this species and clearly showed the prominent "shoulders" at apex and thickened posterior prominence (Fig. 4)

In Asia, H. taichui (Nishigori, 1924) has been reported in animal hosts from Iraq, India, Sri Lanka, Taiwan, Thailand, Malaysia, and the Philippines (Faust and Nishigori, 1926; Pearson and Ow-Yang, 1982; Radomyos et al., 1983, 1998; Waikagul, 1991; Sukontason et al., 2000). In Southeast Asia, human infections of $H$. taichui have only been described from Thailand and the Philippines (Cross, 1974; Waikagul, 1991). This trematode species has been reported from natural and experimental animal infections in the Philippines (Pearson and Ow-Yang, 1982). Natural molluscan (Melania juncea Lea) and picine (Puntius spp. and Ophiocephalus striatus Bloch) species serving as intermediate hosts of this parasite have been described from Luzon and Mindanao (Tubangui, 1947; Velasquez, 1973a, 1973b). The common source of infection for humans likely involves a variety of freshwater fish that serve as a second intermediate host and harbor infective metacercaria encysted in muscle tissue. Humans, domestic dogs, cats, swine, and the bird Bubulcus ibis coromandus (Boddaert) have been reported as definitive hosts of $H$. taichui in the Philippines (Velasquez, 1973a). The full range of intermediate hosts and parasite distribution in the Philippines requires more investigation.

Haplorchine infections have generally been rare in humans but remain a concern because of occasional reports of severe pathologic changes in tissue (e.g., myocarditis) resulting from the minute eggs of heterophyids penetrating through the intestinal wall and lodging in extraintestinal sites (Africa et al., 1935, 1940). High prevalence $(63 \%)$ of H. taichui in humans has been reported as the most common intestinal fluke in northern Thailand (Radomyos et al., 1998), indicating that this parasite can pose a significant health risk in certain endemic foci. In 1998, intestinal parasitism was identified as the second leading cause of morbidity in Monkayo. Hookworm was the most common helminth identified followed by $C$. philippinensis, heterophyid species, A. lumbricoides, and T. trichiura (Monkayo RHU Records, 1998). Intestinal parasite surveys conducted after the discovery of capillariasis in the area in 1998 identified 17 barangays in Mindanao with heterophyid infections (Belizario et al., 2001), representing the largest cluster of endemic heterophyidiasis so far detected in the Philippines and outside Thailand. Based on these findings, we suspect many of the infections were likely the result of $H$. taichui, although 5 other members in the Haplorchinae (Haplorchis Looss, Procerovuom Onji and Nishio, and Stellantchasmus Onji and Nishio) have also been reported to infect humans in the Philippines (Waikagul, 1991).

Local eating habits almost certainly contributed to the high prevalence of H. taichui. The Saug River is a major source of fresh food for the local residents. Most people are fond of consuming a variety of freshwater fish, shrimps, crabs, and frogs. In particular, many freshwater fish are eaten raw and seasoned only with salt and vinegar, a local preparation called kinilaw. Among the local varieties of fish eaten are species of tilapia (Oreochromis sp.), paitan (Hypophthalmichthys mol- itrix), dalag (O. striatus), and buriring (Poecilia sp). Other popular methods of preparing and cooking fish, such as sabaw (boiling for several minutes) and sugba (grilling over charcoal), may result in incomplete cooking of flesh and be an insufficient means to kill the encysted metacecariae. The relatively lower prevalence of infection in sampled groups below $15 \mathrm{yr}$ of age may reflect a lesser tendency to consume raw food preparations compared with adults.

The high prevalence of $H$. taichui found in the southern Philippines would likely have gone undetected had it not been for investigations on intestinal capillariasis in the area. More recent investigations have shown the infection to have a wider distribution in Mindanao than previously reported (V. Y. Belizario Jr., pers. comm.). The underreporting of unusual infections by clinicians is not uncommon because of a lack of familiarity with most trematode infections and the inexperience of laboratory diagnosticians detecting small helminth eggs. A number of factors may have contributed to the high prevalence of $H$. taichui in Monkayo. It has also been speculated that there may have been an increased risk of infection with this parasite, in addition to the C. philippinensis outbreak, a nematode associated with the consumption of raw or undercooked freshwater fish, as an indirect result of the severe drought conditions during the 1997-1998 El Niño Southern Oscillation climatic event. During that time, food crops were in short supply, which likely resulted in an increased reliance on nutrition derived from the river. It would seem reasonable to conclude that periodic climatic anomalies and conditions may influence exposure risk to helminthic infections by changing human behavior and food habits. If such associations exist, the public's awareness of increased risk during times of environmental stress, together with community education on proper hygienic handling and preparation of freshwater fish and the sanitary disposal of human feces, should help diminish the risk of heterophyid infections and other food-borne related parasitic zoonoses (WHO, 1995, 1998). Department of Health efforts continue in Mindanao to identify, treat, and educate affected communities to combat this unpleasant and potentially dangerous helminthic infection.

We extend special thanks for assistance provided by the Center for Health Development for Southern Mindanao, Department of Health, the local government units of Monkayo, Compostela Valley, and Salcedo Eduardo of the University of the Philippines, Los Baños. This study was supported by the Essential National Health Research, Department of Health, RP and the Committee on Research Implementation and Development, College of Medicine, University of the Philippines Manila, with assistance from the U.S. Naval Medical Research and Development Command, Navy Department. The opinions of the authors do not purport to reflect the positions of the U.S. Navy or the Department of Health of the Republic of the Philippines.

\section{LITERATURE CITED}

Africa, C. M., W. E. D de Leon, and E. Y. Garcia. 1935. Intestinal heterophyidiasis with cardiac involvement: A contribution to etiology of heart failure. Journal of the Philippine Islands Medical Association 15: 358-361.

1940. Visceral complications in intestinal heterophyidiasis of man. Acta Medicine Philippina Monograph Series 1: $1-132$.

Ash, L. R., AND T. C. ORiHel. 1987. Parasites: A guide to laboratory procedures and identification. American Society Clinical Pathologists Press, Chicago, Illinois, 328 p.

Belizario, V. Y., M. J. Bersabe, W. U. De Leon, V. Y. Hilomen, G. V. Paller, A. D. DE GuZMan, AND M. G. Bugayong. 2001. Intestinal heterophyidiasis: An emerging food-borne parasitic zoonosis in southern Philippines. Southeast Asian Journal of Tropical Medicine and Public Health 32: 36-42.

, W. U. de Leon, D. G. Esparar, J. M. Galang, J. Fantone, AND C. Verdadero. 2000. Compostela Valley: A new endemic focus for capillariasis philippinensis. Southeast Asian Journal of Tropical Medicine and Public Health 31: 479-481.

Cross, J. H. 1974. Diagnostic methods in intestinal fluke infections: A review. In Diagnostic methods for important helminthiasis and amoebiasis in Southeast Asia and the Far East, C. Harinsuta and D. C. Reynolds (eds.). SEAMEO-TROPMED Project, Bangkok, Thailand, p. 87-108. 
ippines. Monograph SP-47. United States Naval Medical Research Unit 2, Manila, Philippines, 117 p.

Faust, E. C., AND M. Nishigori. 1926. The life cycles of two new species of heterophyidae, parasitic in mammals and birds. Journal of Parasitology 13: 91-132.

Pearson, J. C., AND C. K. Ow-Yang. 1982. New species of Haplorchis from Southeast Asia together with keys to the Haplorchis-group of heterophyid trematodes of the region. Southeast Asian Journal of Tropical Medicine and Public Health 13: 35-60.

Radomyos, B., D. BunNag, AND T. HaRINASUTA. 1983. Haplorchis pumilio (Looss) infection in man in northeastern Thailand. Southeast Asian Journal of Tropical Medicine and Public Health 14: 223227.

, T. Wongsaroj, P. Wilairatana, P. Radomyos, R. Praevanich, V. Meesomboon, and P. Jongsuksuntikul. 1998. Opisthorchiasis and intestinal fluke infections in northern Thailand. Southeast Asian Journal of Tropical Medicine and Public Health 22: 123 127.

Rim, H.-J., H. F. Farag, S. Sornmani, and J. H. Cross. 1994. Foodborne trematodes: Ignored or emerging? Parasitology Today 10: 207-209.
Sukontason, K. L., K. Sukontason, B. Kuntalue, N. Boonsriwong, S. Piangjai, U. Chaithong, and P. Vanittanakom. 2000. Surface ultrastructure of excysted metacercariae of Haplorchis taichui (Trematoda: Heterophyidae). Southeast Asian Journal of Tropical Medicine and Public Health 31: 747-754.

Tubangui, M. A. 1947. A summary of the parasitic worms reported from the Philippines. Philippine Journal of Science. 76: 225-322.

Velasquez, C. C. 1973a. Observations on some heterophyidae (Trematoda: Digenea) encysted in Philippine fishes. Journal of Parasitology 59: $77-84$

. 1973b. Intramolluscan stages of Haplorchis taichui (Nishigori) in Melania juncea Lea in the Philippines. Journal of Parasitology 59: 281.

WAIKAGUL, J. 1991. Intestinal fluke infections in Southeast Asia. Southeast Asian Journal of Tropical Medicine and Public Health 22 Suppl: $158-162$.

WHO. 1995. Control of food-borne trematode infections. Technical Report Series 849. World Health Organization, Geneva, Switzerland, $168 \mathrm{p}$.

WHO. 1998. Guidelines for the evaluation of soil-transmitted helminthiasis and schistosomiasis at community level. WHO/CTD/SIP/ 98.1. World Health Organization, Geneva, Switzerland, 48 p. 